\title{
Pengaruh Kejelasan Peran Dan Motivasi Kerja Terhadap Kinerja Aparatur Sipil Negara Bidang Pengelolaan Barang Milik Daerah
}

\author{
Kasmawati ${ }^{1}$, Syamsu Nujum ${ }^{2}$, Ilham Labbase ${ }^{3}$ \\ ${ }^{1,2,3}$ Magister Manajemen, Universitas Muslim Indonesia. \\ ${ }^{1}$ Koresponden Penulis, E-mail: kasmawaiti.kasmawati@gmail.com
}

\begin{abstract}
ABSTRAK
Penelitian ini dilakukan dengan tujuan: (1) Untuk Mengetahui dan Menganalisis Pengaruh Kejelasan Peran Terhadap Kinerja ASN Bidang Pengelolaan Barang Milik Daerah Provinsi Sulawesi Selatan. (2) Untuk Mengetahui dan Menganalisis Pengaruh Motivasi Kerja Terhadap Kinerja ASN Bidang Pengelolaan Barang Milik Daerah Provinsi Sulawesi Selatan. Metode penelitian yang digunakan dalam penelitian ini adalah Analisis deskriptif dan analisis Regresi Linier Berganda, dengan jumlah sampel sebanyak 50 responden. Berdasarkan hasil analisis regresi linier berganda, maka Hasil penelitian menunjukkan bahwa (1). Kejelasan Peran berpengaruh positif dan Signifikan Terhadap Kinerja ASN Bidang Pengelolaan Barang Milik Daerah Provinsi Sulawesi Selatan. (2) Motivasi Kerja berpengaruh positif dan signifikan Terhadap Kinerja ASN Bidang Pengelolaan Barang Milik Daerah Provinsi Sulawesi Selatan.
\end{abstract}

Kata Kunci: Kejelasan Peran; Motivasi Kerja; Aparatur Sipil Negara

\begin{abstract}
This research was conducted with the aim of: (1) To identify and analyze the effect of role clarity on the performance of civil servants in the field of regional property management in South Sulawesi Province. (2) To determine and analyze the effect of work motivation on the performance of civil servants in the field of regional property management in South Sulawesi Province. The research method used in this research is descriptive analysis and multiple linear regression analysis, with a sample size of 50 respondents. Based on the results of multiple linear regression analysis, the results show that (1). Role clarity has a positive and significant effect on the performance of ASN in the field of regional property management in South Sulawesi province. (2) Work motivation has a positive and significant effect on the performance of ASN in the field of Regional Property Management in South Sulawesi Province.
\end{abstract}

Keywords: Role clarity; Work motivation; State Civil Apparatus 


\section{PENDAHULUAN}

Peraturan Pemerintah Nomor 27 Tahun 2014 menyebutkan bahwa Barang Milik Daerah (BMD) adalah semua barang yang dibeli atau diperoleh atas beban Anggaran Pendapatan dan Belanja Daerah atau berasal dari perolehan lainnya yang sah. Peraturan Pemerintah Nomor 71 Tahun 2010 menyebutkan bahwa aset adalah sumber daya ekonomi yang dikuasai dan/atau dimiliki oleh pemerintah sebagai akibat dari peristiwa masa lalu dan dari mana manfaat ekonomi dan/atau sosial di masa depan diharapkan dapat diperoleh, baik oleh pemerintah maupun masyarakat, serta dapat diukur dalam satuan uang, sosial, maupun politik.

Bagi pengguna informasi akuntansi, nilai $\mathrm{BMD} /$ aset yang tersaji dalam laporan keuangan pemerintah akan digunakan untuk menganalisa kondisi keuangan pemerintah. Jika BMD/aset yang sudah rusak dan tidak digunakan lagi atau BMD yang sudah hilang dan tidak dihapuskan namun masih tetap dilaporkan dalam laporan keuangan, maka pengambilan keputusan yang didasarkan pada informasi tersebut tentu tidak tepat. Berkaitan dengan BMD yang sudah rusak atau hilang, salah satu tindakan yang dapat dilakukan oleh pemerintah terkait dengan permasalahan tersebut adalah tindakan penghapusan BMD. Pengelolaan Barang Milik Daerah (BMD) masih menjadi permasalahan klasik di lingkungan Instansi Pemerintah. Ketidakpedulian atas pentingnya pengelolaan dan pemeliharaan aset yang belum efektif, dapat terlihat dari catatan atas opini Badan Pemeriksa Keuangan (BPK) yang hampir setiap tahun masih didominasi oleh masalah pengelolaan BMD. Permasalahan yang sering ditemukan BPK berdasarkan elemen siklus pengelelolaan BMD antara lain: 1) belum komprehensifnya kerangka kebijakan, 2) persepsi tradisional yang tidak mengedepankan potensi pemanfaatan aset publik bagi pemasukan daerah, 3) inefisiensi, 4) keterbatasan data, 5) keterbatasan SDM (Mardiasmo, et.al 2012).

Manajemen Sumber Daya Manusia mempunyai empat fungsi operasional yang salah satunya adalah menilai dan mengembangkan sumber daya manusia, yang salah satu aktivitasnya adalah menilai kinerja pegawai (Daly 2015). Kinerja adalah hasil pekerjaan yang dicapai seseorang atau kelompok seperti standar hasil kerja, target yang ditentukan selama periode tertentu yang berpedoman pada norma, standard operasional, kriteria dan fungsi yang telah ditetapkan atau yang berlaku dalam organisasi Disamping itu Kinerja dapat diartikan sebagai hasil implementasi rencana kerja yang dibuat oleh suatu institusi yang dilaksanakan oleh pimpinan dan karyawan (SDM) yang bekerja di bidang instansi baik pemerintah maupun perusahaan (bisnis) untuk mencapai tujuan organisasi.

Beberapa peneliti berpendapat bahwa informasi kinerja yang lebih komprehensif dapat membantu memperbaiki kejelasan peran. Secara khusus, informasi kinerja yang komprehensif dapat berfungsi untuk mengklarifikasi peran individu dalam organisasi dengan membuat tujuan spesifik serta perilaku yang sesuai dengan peran kerja (Ilgen et al., 1979) dalam Indiastuti (2019). Dari uraian tersebut salah satu syarat bagi individu dalam melaksanakan tugas serta meningkatkan prestasi kerjanya adalah bagaimana individu tersebut menerima perannya secara jelas. Kejelasan peran ini sangat penting karena jika seorang pegawai tidak tahu apa peran mereka, apa tugas mereka maka pekerjaan yang ada dalam organisasi tersebut tidak akan 
terselesaikan dengan optimal atau bahkan tujuan organisasi yang telah ditetapkan tidak akan terwujud (Moonti, et,al, 2017) .

Kejelasan peran dianggap sebagai titik awal dari pemberdayaan psikologis dari individu. Individu yang tidak memiliki tanggung jawab yang jelas dan tidak tahu bagaimana untuk mencapai hal tersebut, maka mereka cenderung tidak mempercayai bahwa mereka memiliki keterampilan yang dibutuhkan dan kemampuan untuk mengerjakan sebuah tugas dengan layak atau merasa kurang diberdayakan (Arambewela \& Hall, 2004). Spreitzer (1996) menyatakan bahwa untuk menciptakan tujuan yang jelas, maka tugas dan lini tanggung jawab harus dapat meningkatkan pemberdayaan psikologis dalam lingkungan kerja mereka.

Hasil penelitian dari (Conger dan Kanugo, 1988) membuktikan bahwa batasan yang jelas dari tanggung jawab dan wewenang berhubungan positif dengan persepsi kepercayaan diri dari individu. Persyaratan tugas yang jelas dan rendahnya ketidakpastian juga berkaitan erat dengan perasaan individu terhadap kompetensi diri (Gist dan Mitchell, 1992). Keterampilan dan kompetensi individu akan bermanfaat jika individu memiliki kejelasan tujuan kerja dan memahami proses yang ditempuh untuk mencapai tujuan tersebut.

Kejelasan peran juga akan menciptakan perasaan mampu mengambil keputusan sendiri dan mengambil tindakan untuk melakukan tugas tersebut sehingga seorang individu akan leluasa menentuan diri di wilayah kerja mereka (Spreitzer et al, 1997). Rendahnya kejelasan peran berkaitan dengan individu yang merasa kurang diberdayakan akan mengurangi persepsi pengaruh (Impact) dalam lingkungan kerja.

Pemaduan kebutuhan inilah yang lajim disebut dengan motivasi. Dari diindikasi dua akibat tersebut di atas, dapat dikatakan bahwa ketidakefektifan pelaksanaan tugas lebih banyak disebabkan oleh ketidakjelasan peran dan motivasi kerja. Muhammad Anggriawan (2017), kejelasan peran, keadilan prosedural, dan motivasi berpengaruh signifikan terhadap kinerja manajerial tetapi pengukuran kinerja non finansial tidak berpengaruh signifikan terhadap kinerja manajerial.

Anehnya, kejelasan peran, keadilan prosedural, dan motivasi memiliki efek mediasi antara pengukuran kinerja non finansial pada kinerja manajerial. Berdasarkan latar belakang diatas maka penulis tertarik kembali melakukan penelitian dengan mengambil topic pengaruh kejelasan peran dan motivasi terhadap kinerja ASN pada Instansi Badan Pengelola Keuangan Daeran bidang Pengelolaan Aset di Pemerintah Provinsi Sulawesi Selatan

Berdasarkan uraian tersebut, maka kerangka konseptual penelitian ini adalah: 


\section{Gambar 1. Kerangka Konseptual}

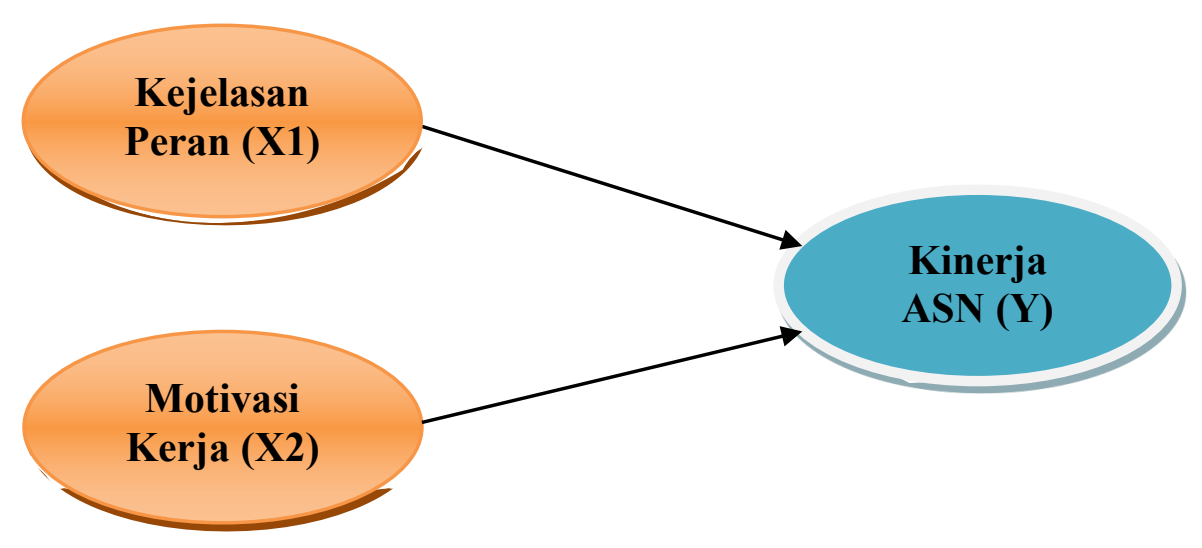

\section{Hipotesis}

Berdasarkan latar belakang masalah dan kajian teori maka hipotesis dalam penelitian ini yaitu :

1. Kejelasan peran berpengaruh positif dan signifikan terhadap kinerja ASN Bidang Pengelolaan Barang Milik Daerah Provinsi Sulawesi selatan.

2. Motivasi Kerja berpengaruh positif dan signifikan terhadap kinerja ASN Bidang Pengelolaan Barang Milik Daerah Provinsi Sulawesi selatan.

\section{METODE PENELITIAN}

Pendekatan yang digunakan dalam penelitian ini adalah penelitian kuantitatif. Yaitu metode penelitian yang menekankan pada fenomene-fenomena yang obyektif dan di gunakan untuk meneliti populasi atau sampel-sampel tertentu. Adapun hasil dari penelitian merupakan generalisasi dan prediksi berdasarkan hasil-hasil pengukuran yang kebenaran hasil penelitiannya didukung oleh validitas cara/alat yang digunakan. Lokasi penelitian dalam penelitian ini adalah Kantor Badan Pengelolaan Keuangan dan Aset Daerah Provinsi Sulawesi Selatan Khususnya Bidang Pengelolaan Barang Milik Daerah yang berlokasi di Jl. Urip Sumiharjo Kota Makassar, dengan waktu penelitian selama 2 bulan terhitung sejak bulan April sampai dengan Juni 2020.

\section{Hipotesis}

a. Koefisien Determinasi $\left(\mathrm{r}^{2}\right)$

$\mathrm{r}^{2}$ diartikan sebagai proporsi variasi tanggapan yang diterangkan oleh regresor (variabel bebas / X) dalam model. Dengan demikian, jika $\mathrm{r}^{2}=1$ akan mempunyai arti bahwa model yang sesuai menerangkan semua variabilitas dalam variabel $Y$. jika $\mathrm{r}^{2}=0$ akan mempunyai arti bahwa tidak ada hubungan antara regresor $(X)$ dengan variabel $Y$. Dalam kasus misalnya jika $\mathrm{r}^{2}=0,8$ mempunyai arti bahwa sebesar $80 \%$ variasi dari variabel $\mathrm{Y}$ (variabel tergantung/response) dapat diterangkan dengan variabel X (variabel bebas / explanatory); sedang sisanya 0,2 
dipengaruhi oleh variable-variabel yang tidak diketahui atau variabilitas yang inheren. b. Uji F.

Untuk mengetahui apakah variabel independen berpengaruh signifikan terhadap variabel dependen, dilakukan perbandingan antara $F_{\text {hitung }}$ dengan $F_{\text {tabel }}$ pada tingkat kepercayaan $95 \%(\alpha=0,05)$ dengan kaidah pengambilan keputusan sebagai berikut :

a. Jika $F_{\text {hitung }}>F_{\text {tabel }}$ pada tingkat kepercayaan $95 \%$ atau $\alpha=0,05$, maka terbukti semua variabel independen yang diamati secara serempak berpengaruh signifikan terhadap faktor dependen.

b. Jika $F_{\text {hitung }}<\mathrm{F}_{\text {tabel }}$ pada tingkat kepercayaan $95 \%$ atau $\mathrm{a}=0,05$ akan membuktikan bahwa semua faktor independen yang diamati secara serempak tidak memberikan pengaruh signifikan terhadap faktor dependen.

Nilai $F$ hitung diperoleh dari hasil perhitungan statistik (SPSS) dalam tabel ANOVA.Sedangkan $\mathrm{F}$ tabel diperoleh dengan melihat tabel $\mathrm{F}$ (sesuai dengan tingkat kepercayaan yang ditentukan) dengan caradf1, $d f 2$. Nilai $d f 1=$ jumlah dari variabel bebas, $d f 2=\mathrm{N}-\mathrm{k}-1$, dimana $\mathrm{N}=$ jumlah sampel, dan $\mathrm{k}=$ jumlah variabel bebas.

Berdasarkan tabel ANOVA (hasil uji SPSS) juga diperoleh koefisien determinasi $\left(R^{2}\right)$. Nilai koefisien determinasi $\left(R^{2}\right)$ berada antara $1<R^{2}, 0$ jika $R^{2}$ mendekati 1 , maka model regresi linier berganda dinilai sangat kuat.

b. Uji T

Uji $\mathrm{t}$ dikenal dengan uji parsial, yaitu untuk menguji bagaimana pengaruh masing-masing variabel bebasnya secara sendiri - sendiri terhadap variabel terikatnya (Ghozali, 2006). Uji ini dapat dilakukan dengan mambandingkan $\mathrm{t}$ hitung dengan $\mathrm{t}$ tabel atau dengan melihat kolom signifikansi pada masingmasing $t$ hitung, proses uji $t$ identik dengan Uji F (lihat perhitungan SPSS pada Coefficient Regression Full Model). Atau bisa diganti dengan Uji metode Stepwise.

\section{HASIL PENELITIAN DAN PEMBAHASAN}

\section{Hasil}

\section{A. Uji Validitas dan Reliabilitas}

Tabel 1. Uji Validitas

\begin{tabular}{ccccc}
\hline Variabel & Item & r-hitung & r-tabel & Keterangan \\
\cline { 2 - 5 } & 1 & 0,809 & 0,278 & Valid \\
\cline { 2 - 5 } & 2 & 0,731 & 0,278 & Valid \\
\cline { 2 - 5 } X1 & 3 & 0,665 & 0,278 & Valid \\
\cline { 2 - 5 } Kejelasan Peran & 4 & 0,595 & 0,278 & Valid \\
\cline { 2 - 5 } & 5 & 0,650 & 0,278 & Valid \\
\hline Variabel & Item & r-hitung & r-tabel & Keterangan \\
\hline & 1 & 0,711 & 0,278 & Valid \\
\hline
\end{tabular}




\begin{tabular}{ccccc}
\hline X2 & 2 & 0,705 & 0,278 & Valid \\
\cline { 2 - 5 } Motivasi Kerja & 3 & 0,656 & 0,278 & Valid \\
\cline { 2 - 5 } & 4 & 0,615 & 0,278 & Valid \\
\cline { 2 - 5 } & 5 & 0,613 & 0,278 & Valid \\
\cline { 2 - 5 } & 6 & 0,763 & 0,278 & Valid \\
\hline Variabel & Item & r-hitung & r-tabel & Keterangan \\
\hline Y & 1 & 0,763 & 0,278 & Valid \\
\hline Kinerja ASN & 2 & 0,671 & 0,278 & Valid \\
\cline { 2 - 5 } & 3 & 0,671 & 0,278 & Valid \\
\cline { 2 - 5 } & 4 & 0,545 & 0,278 & Valid \\
\cline { 2 - 5 } & 5 & 0,746 & 0,278 & Valid \\
\hline
\end{tabular}

\section{Data Olahan SPSS-2020}

Berdasarkan tabel 1 diatas, maka semua variabel dalam penelitian ini memiliki nilai $\mathrm{r}$ hitung lebih besar dari $\mathrm{r}$ tabel yaitu 0,278, sehingga item-item pertanyaan dalam penelitian ini dapat dikatakan valid. Suatu kuesioner dikatakan reliabel jika jawaban responden terhadap pertanyaan adalah konsisten dari waktu ke waktu, sebuah variabel dikatakan valid apabila nilai Cronbach's Alpha > 60\% (Ghozali, 2006). Sementara itu untuk melihat uji relibilitas kuisener, maka digunakan uji relibilitas sebagaimana terdapat dalam tabel dibawah ini:

Tabel 2. Hasil Uji Reliabilitas

\begin{tabular}{lcc}
\multicolumn{1}{c}{ Variabel } & Cronbach Alpha & Ket \\
\hline X1. Kejelasan Peran & 0,862 & Reliabel \\
\hline X2. Motivasi Kerja & 0,837 & Reliabel \\
\hline Y. Kinerja ASN & 0,842 & Reliabel \\
\hline
\end{tabular}

Sumber data: Hasil Olahan SPSS

Berdasarkan tabel diatas maka semua variabel penelitian memiliki nilai Cronbach Alpha lebih besar dari nilai standar yaitu 0,60 sehingga item-item pertanyaan dalam penelitian ini dapat dikatakan relibel.

\section{B. Uji Asumsi Klasik}

Uji asumsi klasik adalah persyaratan statistik yang harus dipenuhi pada analisis regresi linear berganda yang berbasis ordinary least square (OLS). Jadi analisis regresi yang tidak berdasarkan OLS tidak memerlukan persyaratan asumsi klasik, misalnya regresi logistik atau regresi ordinal. Demikian juga tidak semua uji asumsi klasik harus dilakukan pada analisis regresi linear, misalnya uji multikolinearitas tidak dilakukan pada analisis regresi linear sederhana dan uji autokorelasi tidak perlu diterapkan pada data cross sectional. Uji asumsi klasik yang sering digunakan yaitu uji multikolinearitas, uji heteroskedastisitas, uji normalitas, uji autokorelasi dan uji linearitas. Tidak ada ketentuan yang pasti tentang urutan uji mana dulu yang harus dipenuhi. 


\section{Uji Normalitas}

Uji normalitas dapat digunakan untuk melihat apakah nilai residual terdistribusi normal atau tidak. Model regresi yang baik adalah memiliki nilai residual yang terdistribusi normal. Jadi uji normalitas bukan dilakukan pada masing-masing variabel tetapi pada nilai residualnya. Sering terjadi kesalahan yang jamak yaitu bahwa uji normalitas dilakukan pada masing-masing variabel. Hal ini tidak dilarang tetapi model regresi memerlukan normalitas pada nilai residualnya bukan pada masing-masing variabel penelitian. Uji normalitas dapat dilakukan dengan uji histogram, uji normal P Plot, uji Chi Square, Skewness dan Kurtosis atau uji Kolmogorov Smirnov. Tidak ada metode yang paling baik atau paling tepat. Tipsnya adalah bahwa pengujian dengan metode grafik sering menimbulkan perbedaan persepsi di antara beberapa pengamat, sehingga penggunaan uji normalitas dengan uji statistik bebas dari keragu-raguan, meskipun tidak ada jaminan bahwa pengujian dengan uji statistik lebih baik dari pada pengujian dengan metode grafik.

Dasar pengambilan keputusannya menurut (Santoso, 2000) yaitu :Jika data menyebar disekitar garis diagonal dan mengikuti arah garis, maka model regresi memenuhi asumsi normalitas. Dengan demikian karena grafik memenuhi asumsi maka model regresi memenuhi syarat uji normalitas (lihat lampiran)

\section{Uji Heteroskedastisitas}

Uji heteroskedastisitas adalah untuk melihat apakah terdapat ketidaksamaan varians dari residual yang satu ke pengamatan yang lain. Model regresi yang memenuhi persyaratan adalah di mana terdapat kesamaan varians dari residual satu pengamatan ke pengamatan yang lain tetap atau disebut homoskedastisitas. Deteksi heteroskedastisitas dapat dilakukan dengan metode scatter plot dengan memplotkan nilai ZPRED (nilai prediksi) dengan SRESID (nilai residualnya). Model yang baik didapatkan jika tidak terdapat pola tertentu pada grafik, seperti mengumpul di tengah, menyempit kemudian melebar atau sebaliknya melebar kemudian menyempit.

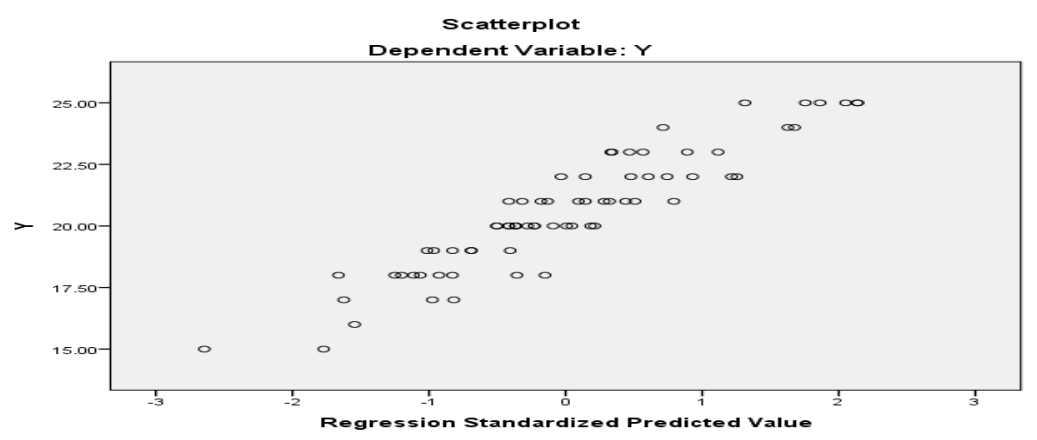

Uji statistik yang dapat digunakan adalah uji Glejser, uji Park atau uji White. Beberapa alternatif solusi jika model menyalahi asumsi heteroskedastisitas adalah dengan mentransformasikan ke dalam bentuk logaritma, yang hanya dapat dilakukan jika semua data bernilai positif. Atau dapat juga dilakukan dengan membagi semua variabel dengan variabel yang mengalami gangguan heteroskedastisitas. uji homoskedastisitas dapat dilihat dari perbandingan nilai $\mathrm{t}$ dengan nilai signifikan sebaga berikut: 
Tabel 3. Uji Heteroskedastisitas

\begin{tabular}{ccccc} 
No & Variabel & Nilai $t$ & Nilai Sig & Keterangan \\
\hline 1 & X1 atas Y & 5.286 & .000 & Ada hubugan \\
\hline 2 & X2 atas Y & 3.006 & .004 & Ada hubugan \\
\hline
\end{tabular}

Sumber :Data Primer Diolah

Menurut (Santoso, 2000) model regresi yang baik adalah tidak terjadi heteroskedastisitas. Tampak pada gambar diatas menunjukkan tidak terjadinya heteroskedastisitas. Ini ditandai dengan tidak adanya pola yang jelas, serta titik menyebar diatas dan dibawah angka 0 pada sumbu $Y$.

\section{Uji Multikolinieritas}

Tabel. 4 Uji Multikolinieritas

\begin{tabular}{|l|l|r|r|r|r|r|}
\hline \multicolumn{9}{|c|}{ Coefficients $^{\mathbf{a}}$} \\
\hline \multirow{2}{*}{\begin{tabular}{l} 
Model \\
\cline { 3 - 7 }
\end{tabular}} & \multicolumn{2}{|c|}{ Correlations } & \multicolumn{2}{c|}{ Collinearity Statistics } \\
\cline { 2 - 7 } & Kejelasan Peran & .778 & .611 & .444 & .602 & 1.661 \\
\cline { 2 - 7 } & Motivasi Kerja & .686 & .402 & .252 & .602 & 1.661 \\
\hline
\end{tabular}

Data Olahan SPSS 2020

Berdasarkan tabel diatas maka dapat dikatakan bahwa model regresi memenuhi syarat uji multikolineritas. Sebagaimana dilihat pada kolom VIF hasil uji SPSS 24 yang berada disekitar angka 1 dan kolom tolerance mendekati angka 1. (Ghozali, 2002). Pada pendekatan yang lain, tabel korelasi menunjukkan hasil analisis interkorelasi antara variabel bebas yang ditandai dengan nilai koefisien korelasi pearson pada out put SPSS.. Uji multikolinearitas dilakukan dengan melihat nilai toleransi lebih besar dari 10\%(0,10) dengan Variace Inflation Factor(VIF) kurang dari 10, maka tidak terdapat multikolinearitas. Selanjutnya akan kita pastikan dengan melihat cara deteksi multikolinearitas lainnya, yaitu berdasarkan nilai standar error dan koefisien beta regresi parsial. Dalam tabel coefficient nilai standar error kurang dari satu dimana $\mathrm{X} 1=0,121$ dan $\mathrm{X} 2=0,110$, Maka dapat dikatakan bahwa nilai standar error rendah dan multikolinearitas tidak terdeteksi.

\section{Analisis Regresi Linier Berganda}

Tabel.5. Hasil Olahan Data Regresi Linier Berganda

\begin{tabular}{|c|c|c|c|c|c|c|}
\hline \multicolumn{7}{|c|}{ Coefficientsa } \\
\hline & & \multicolumn{2}{|c|}{ Unstandardized Coefficients } & $\begin{array}{l}\text { Standardized } \\
\text { Coefficients }\end{array}$ & \multirow[b]{2}{*}{$t$} & \multirow[b]{2}{*}{ Sig. } \\
\hline \multicolumn{2}{|c|}{ Model } & $\mathrm{B}$ & Std. Error & Beta & & \\
\hline \multirow[t]{3}{*}{1} & (Constant) & .102 & .421 & & .243 & .809 \\
\hline & Kejelasan Peran & .642 & .121 & .572 & 5.286 & .000 \\
\hline & Motivasi Kerja & .331 & .110 & .325 & 3.006 & .004 \\
\hline
\end{tabular}

Sumber: Data hasil olahan SPSS 
Tabel diatas diketahui bahwa nilai konstan yaitu b0 $=0.102$, variabel Kejelasan Peran $\left(X_{1}\right)$ sebesar 0,642 , variabel Motivasi kerja ,0.331, sehingga persamaan regresi dapat dilihat sebagai berikut:

$$
Y=0.102+0,642 X_{1}+0,331 X_{2}
$$

Nilai konstan yaitu b0 $=0,102$, mempunyai arti bahwa, apabila variabel Kejelasan Peran $\left(X_{1}\right)$ variabel dan Motivasi Kerja $\left(X_{2}\right)$ tidak mengalami perubahan maka Kinerja ASN sebesar 0.102, atau 10,2\%

- Koefisien variabel Kejelasan Peran ( $\left.\mathbf{X}_{\mathbf{1}}\right)$ sebesar 0,642, hal ini berarti bahwa apabila Kejelasan Peran dilaksanakan dengan baik maka akan meningkatkan Kinerja ASN, dimana setiap peningkatan dalam Kejelasan Peran akan meningkatkan Kinerja ASN, dengan asumsi variabel X2 memiliki nilai konstan.

- Koefisien variabel Motivasi Kerja $\left(\mathbf{X}_{2}\right)$ sebesar 0.331, hal ini berarti bahwa semakin tinggi Motivasi Kerja, maka akan meningkatkan Kinerja ASN, dimana setiap peningkatan dalam Motivasi Kerja akan mendorong Kinerja ASN, dengan asumsi Variabel X1 bernilai konstan.

- Besarnya nilai koefisien korelasi berganda (R) adalah 0.818, hal ini menunjukan bahwa besarnya hubungan antara variabel independent $\mathrm{X} 1$, dan $\mathrm{X} 2$, dengan Variabel Dependen (Y) yaitu Kinerja ASN sebesar 0.818 atau 81,8 dan hal ini menunjukkan bahwa variabel Kejelasan Peran (X1), Motivasi Kerja (X2), secara bersama-sama mempunyai hubungan terhadap Kinerja ASN Bidang Pengelolaan Barang Milik Daerah Provinsi Sulawesi Selatan.

Besarnya nilai koefisien determinasi $\left(\mathbf{R}^{2}\right)$ adalah 0.668 , hal ini menunjukan bahwa besarnya pengaruh variabel independen $(\mathbf{X})$ terhadap Kinerja ASN sebesar 0.668 atau $(66,8)$ dan sisanya sebesar 0.332 atau 33,2 dipengaruhi oleh faktor atau variabel lain yang tidak dimasukan dalam model penelitian ini.

\section{E. Pengujian Hipotesis}

\section{- Uji F (Uji Simultan)}

Pengujian ini dimaksudkan untuk mengetahui bagaimana variabel independent (bebas) yang terdiri Kejelasan Peran (X1) Motivasi Kerja $\left(X_{2}\right)$, secara simultan (bersama sama) berpengaruh terhadap Kinerja ASN. Pada tampila out put SPSS diatas diperoleh F-hitung $=47.369>\mathrm{F}_{\text {tabel }}=3,19(\mathrm{df} 1=2$, df2 $=48)$ serta memiliki tingkat signifikansi 0,000 . Karena probabilitas 0,000 jauh lebih kecil dari 0,05, maka dapat dikatakan bahwa model regresi yang telah digunakan ini dapat meningkatkan Kinerja ASN Bidang Pengelolaan Barang Milik daerah Provinsi Sulawesi Selatan.

\section{- $\quad$ Uji t (Uji Parsial)}

Untuk mengetahui pengaruh secara parsial dari masing-masing variabel independen Kejelasan Peran $\left(X_{1}\right)$ variabel Motivasi Kerja X2 terhadap Kinerja ASN Bidang Pengelolaan Barang Milik daerah Provinsi Sulawesi Selatan maka berikut ini akan dijelaskan sebagai berikut: 


\section{1) Variabel Kejelasan Peran $X_{1}$}

Berdasarkan hasil penelitian yang menguji pengaruh Kejelasan Peran terhadap Kinerja ASN dapat dilihat dari nilai $\mathrm{t}$ hitung $=5,286>\mathrm{t}$ tabel $=1,677$ dengan tingkat signifikansi sebesar 0,000, lebih kecil jika dibandingkan dengan tingkat signifikan $a=5 \%$. Hasil ini menunjukkan bahwa secara perhitungan statistik Kejelasan Peran berpengaruh terhadap Kinerja ASN Bidang Pengelolaan Barang Milik Daerah Provinsi Sulawesi Selatan.. Dengan demikian hipotesis pertama yang menyatakan bahwa Kejelasan Peran berpengaruh terhadap Kinerja ASN terbukti (H1 diterima).

\section{2). Variabel Motivasi Kerja $\mathbf{X}_{2}$}

Berdasarkan hasil penelitian yang menguji pengaruh Motivasi Kerja terhadap Kinerja ASN diperoleh nilai $t_{\text {hitung }}=3.006>t$ - tabel $=1,677$ dengan tingkat signifikansi sebesar 0,004, lebih kecil jika dibandingkan dengan tingkat $a=5 \%$. Hasil ini menunjukkan bahwa secara perhitungan statistik Motivasi Kerja berpengaruh terhadap Kinerja ASN Bidang Pengelolaan Barang Milik Daerah Provinsi Sulawesi Selatan. Dengan demikian hipotesis kedua yang menyatakan bahwa Motivasi Kerja berpengaruh terhadap Kinerja ASN terbukti (H2 diterima).

\section{Pembahasan}

\section{Pengaruh Kejelasan Peran Terhadap Kinerja}

Berdasarkan hasil penelitian ditemukan bahwa kejelasan peran berpengaruh positif dan signifikan terhadap kinerja ASN Bidang Pengelolaan Barang Milik daerah Provinsi Sulawesi Selatan. Hasil penelitian secara statistik membuktikan bahwa hipotesis pertama yang menyatakan bahwa kejelasan peran berpengaruh positif dan signifikan terhadap kinerja ASN dapat diterima. Hasil penelitian ini juga didukung dengan kecenderungan jawaban responden dari kuisener penelitian.

Berdasarkan jawaban responden penelitian, kejelasan peran dalam penelitian ini menggunkan beberapa indikator yaitu Indiaktor pertama Person Role Set. Indiaktor ini memiliki dua pernyataan yaitu Pada instansi tempat Saya bekerja, kejelasan rencana kerja dan Tugas pokok telah terdefinisikan dengan jelas dan komprehensif. Jawaban responden mengindiaksikan bahwa ASN yang bekerja pada Bidang pengelolaan Barang Milik Daerah di Provinsi Sulawesi selatan dominan telah mengakui bahwa rencana kerja dan tugas pokok (Tupoksi) telah diatur dengan baik dan jelas untuk masing-masing unit pelaksana pekerjaan.

Temuan penelitian ini sejalan dengan penelitian Syelviani Meilisa (2017), yang menemukan bahwa terdapat pengaruh yang signifikan antara deskripsi kerja terhadap kinerja pegawai negeri sipil di kantor camat Tembilahan. Temuan yang juga sejalan dengan penelitian ini adalah penelitian Sevvy Yossa, Zunaidah. (2013) dalam penelitiannya menemukan bahwa Deskripsi pekerjaan secara signifikan dan dominat mempengaruhi kinerja PT. Pelabuhan Indonesia II (Persero) Cabang Palembang. Hal ini juga relevan dengan teori yang dikemukakan oleh Hasibuan 
(2005), bahwa deskripsi pekerjaan (job description) adalah informasi tertulis yang menguraikan tugas dan tanggung jawab, kondisi pekerjaan, hubungan pekerjaan dan aspek-aspek pekerjaan pada suatu jabatan tertentu dalam organisasi.

\section{Pengaruh Motivasi Kerja Terhadap Kinerja.}

Berdasarkan hasil penelitian, ditemukan bahwa motivasi kerja berpengaruh positif dan signifikan terhadap kinerja ASN. Hasil penelitian ini membuktikan bahwa hipotesis kedua dalam penelitian ini yang menyatakan bahwa motivasi kerja berpengaruh positif dan signifikan terhadap kinerja ASN Bidang pengelolaan barang milik daerah provinsi sulawesi selatan dapat diterima. Berdasarkan jawaban responden pada indikator pertama yaitu Prestasi (Achievement). Indikator ini memiliki dua pernyataan, yang secara rata-rata memiliki nilai ideal. Jawaban responden pada indikator ini menunjukan bahwa masih terdapat ASN yang manyatakan kurang setuju dengan pernyataan yang terkait dengan objektivitas dalam penilaian prestasi kerja. Peneliaian ini tentunya berdasar pada kegiatan yang dilaksanakan, dan yang diikuti oleh ASN. Begitu pula dalam pernyataan kedua yang terkait dengan medi yang disediakan organisasi dalam penilaian prestasi kerja ASN. Penilaian kinerja ((performance appraisal) adalah proses mengevaluasi seberapa baik Sumber Daya Manusia dalam melakukan pekerjaan mereka jika dibandingkan dengan seperangkat standar, dan kemudian mengkomunikasikan informasi tersebut kepada Sumber Daya Manusia.

Penilaian Kinerja juga disebut pemeringkatan/rangking pegawai, evaluasi pegawai, tinjauan kerja, evaluasi kinerja dan penilaian hasil kerja (Mathis dan Jackson, 2006: 382). Penilaian prestasi kerja Pegawai Negeri Sipil secara strategis diarahkan sebagai pengendalian perilaku kerja produktif yang disyaratkan untuk mencapai hasil kerja yang disepakati dan bukan penilaian atas kepribadian seseorang Pegawai Negeri Sipil. Unsur perilaku kerja yang mempengaruhi prestasi kerja yang dievaluasi memang relevan dan secara signifikan berhubungan dengan pelaksanaan tugas pekerjaan dalam jenjang jabatan setiap individu Pegawai Negeri Sipil yang dinilai. Untuk mencapai obyektifitas penilaian prestasi kerja Pegwai Negeri Sipil, diperlukan parameter penilaian sebagai ukuran dan standar penilaian hasil kerja yang nyata dan terukur.

Hasil penelitian ini sejalan dengan penelitian Arfina (2018), bahwa efektifitas penilaian prestasi kerja didasarkan pada kegiatan yang telah dilaksanakan seperti pemantauan, pelaksanaan kehadiran/disiplin, pertangungjawaban dalam pembuatan laporan hasil kerja, kehadiran dalam rapat kerja, pemeriksaan dan pengawasan, kesemuanya merupakan salah satu produk keberhasilan pegawai dalam penilaian dan peningkatan prestasi kerja bagi aparatur. Pengaturan lebih lanjut masalah penilaian prestasi kerja ini dilakukan dengan menggunakan aplikasi e-kinerja.

\section{KESIMPULAN}

Berdasarkan hasil analisis dan pembahasan yang telah diuraikan sebelumnya, maka selanjutnya akan disajikan beberapa kesimpulan yaitu sebagai berikut : 
1. Kejelasan peran berpengaruh positif dan signifikan terhadap kinerja ASN Bidang pengelolaan Barang Miliki Daerah Provinsi Sulawesi Selatan. Hasil penelitian dapat membuktikan hipotesis yang mengatakan bahwa Kejelasan Peran berpengaruh positif dan signifikan terhadap kinerja ASN dapat diterima atau terbukti.

2. Motivasi kerja berpengaruh positif dan signifikan terhadap kienerka ASN Bidang Pengelolaan Barang Milik Daerah Provinsi Sulawesi Selatan. Hasil ini menunjukan bahwa hipotesis kedua yang menyatakan bahwa Motivasi Kerja berpengaruh positif dan signifikan terhadap kinerja ASN dapat terbukti atau diterima.

\section{DAFTAR PUSTAKA}

Arambewela, R. \& Hall, J. (2004). An empirical model of international student satisfaction. Asia Pacific Journal of Marketing and Logistics, 21(4): p. 555-569.

Arfina (2018), Efektifitas Penilaian Prestasi Kerja Pegawai Terhadap Promosi Jabatan Pada Badan Kepegawaian Dan Pendidikan Pelatihan Daerah Kabupaten Buton. Kybernan : Jurnal Studi Kepemerintahan Vol. 2 No. 1 Bulan April 2018 P-ISSN: 25022539.

Conger, J. A., \& Kanungo, R. N. (1988). The Empowerment Process: Integrating Theory and Practice. Academy of Management Review, 13, 471-482.

Ghozali, I. (2006). Aplikasi analisis multivariate dengan program SPSS. Badan Penerbit Universitas Diponegoro.

Gist, M. E., dan Mitchell. (1992). Self efficacy: a theoretical analysis of its determinants and malleability, Academy of Management Review, Vol 17 No 2: 183-211.

Ilgen, D. R., Fisher, C. D., \& Taylor, M. S. (1979). Consequences of individual feedback on behavior in organizations. Journal of Applied Psychology, 64: 349-371.

Anggriawan, M. (2017). Efek Mediasi Kejelasan Peran, Keadilan Prosedural Dan Motivasi Pada Pengaruh Pengukuran Kinerja Nonfinansial Terhadap Kinerja Manajerial. JRA TIRTAYASA VOLUME 03 NO 02 Oktober 2018.

Mardiasmo, D. (2012). State asset management reform in Indonesia : a wicked problem Dissertation/Thesis. Queensland University of Technology.

Moonti, R. M., Ismail, N., Karepoan, J. K., \& Djanggih, H. (2018). Pelaksanaan Pengukuran Prestasi Kerja Terhadap Aparatur Sipil Negara (ASN) di Dinas Pertanian Provinsi Gorontalo. Jurnal Ilmiah Kebijakan Hukum, 12(2), 151-161.

Santoso, S. (2000). Buku latihan SPSS statistik parametrik. Penerbit Elex Media Komputindo

Spreitzer, G.M. 1996. Social Structural Characteristics of Psychological Empowerment. Academy of Management Journal, 39(2), 483-504,

Spreitzer, G.M. 1997. Toward a common ground in defining empowerment. Research in Organizational Change and Development, 10, 31-62. 
Syelviani Meilisa (2017). The Effect Of Job Description On Civil Servant's Performance In Tembilahan Subdistrict Office. Journal of Economy, Business and Accounting (COSTING) Volume1, No1, Desember 2017 e-ISSN : 2597-5234. 